\title{
Reparations for Police Killings
}

\author{
Jennifer M. Page
}

\begin{abstract}
After a fatal police shooting, it is typical for city and police officials to view the family of the deceased through the lens of the law. If the family files a lawsuit, the city and police department consider it their legal right to defend themselves and to treat the plaintiffs as adversaries. However, reparations and the concept of "reparative justice" allow authorities to frame police killings in moral rather than legal terms. When a police officer kills a person who was not liable to this outcome, officials should offer monetary reparations, an apology, and other redress measures to the victim's family. To make this argument, the article presents a philosophical account of non-liability hailing from self-defense theory that centers on the distinction between reasonableness and liability. Reparations provide a nonadversarial alternative to civil litigation after a non-liable person has been killed by a police officer. In cases where the officer nevertheless acted reasonably, "institutional agent-regret" rather than moral responsibility grounds the argument for reparations. Throughout the article, it is argued that there are distinct racial wrongs both when police kill a nonliable black person and when family members of a black victim are treated poorly by officials in the civil litigation process.
\end{abstract}

$\square$ n July 19, 2015, Samuel DuBose, an unarmed black man, was shot and killed at a traffic stop by Ray Tensing, a white University of Cincinnati police officer. Tensing was indicted, and the following January, talks between DuBose's family and the University of Cincinnati produced an agreement containing the following provisions: a substantial monetary redress payment, an official apology from the university president, an on-campus memorial, tuition-free college for DuBose's children, and the establishment of a community advisory

Jennifer M. Page (D) is a postdoctoral researcher in political philosophy at the University of Zurich's Center for Ethics (jennifer.page@uzh.ch).She has authored and coauthored essays appearing in Social Theory and Practice, Ethnic and Racial Studies, Raisons Politiques, and the Routledge Handbook of Ethics and Public Policy and is working on a book about reparations.

Versions of this article were presented at the University of Connecticut's Political Violence Workshop, the MANCEPT Workshops in Political Theory, the American Political Science Association Annual Meeting, the University of Iceland's "Who's Got The Power?" Conference, and the Political Philosophy Colloquium and CIS Annual Colloquium at the University of Zurich. The author is grateful for the comments received at all these venues, as well as to Aurélia Bardon, Leonard Feldman, Jessica Simes, and Marian Page. The financial support of Brown University's Center for the Study of Slavery and Justice and the University of Zurich's Political Philosophy Chair made the numerous presentations of this article possible. council on police reform with a seat reserved for a member of DuBose's family ("University of Cincinnati" 2016).

Contrast this response to one that occurred after tragic events in another Ohio city less than a year earlier. Tamir Rice, an African American 12-year-old boy playing with a toy gun, was shot by Cleveland police on November 22, 2014 and died the next day. A video recording shows Timothy Loehmann, a white officer, opening fire on Tamir within seconds of arriving at the scene. Tamir's 14-year-old sister ran to her younger brother's side, but was handcuffed and placed in the backseat of the patrol car; several critical minutes passed before anyone tried to administer aid. Loehmann escaped without criminal charges. Prosecutor Timothy McGinty recommended non-indictment to the grand jury, arguing that the officer did not know that the gun was a toy and had "a reason to fear for his life" (Williams and Smith 2015). Tamir's mother, Samaria Rice, initiated litigation against the city and the officers. A lengthy, highly public civil lawsuit ensued, with the city of Cleveland's attorneys mounting a vigorous defense against all allegations.

Focusing on the United States, this article lays out a normative argument for the use of reparative justice measures in responding to fatal police shootings. Taking the University of Cincinnati's response to the death of Samuel DuBose as a starting point, I use the term "reparative justice measures" to refer to monetary redress and a range of other material and symbolic forms of reparations. ${ }^{1}$ On my account, police and city officials should offer a monetary sum commensurate with the outcome of a successful wrongful death lawsuit and an official apology, and initiate talks with the family members of the deceased about other redress measures they feel are appropriate. In offering monetary redress, officials should 
emphasize that it is not intended as blood money or hush money, but that the aim is to save the family from the emotional stress of a civil lawsuit that is their right to proceed with. $^{2}$

In what circumstances should authorities offer reparations? Don't complex matters of fact often complicate the question as to whether the use of lethal force was warranted? In the United States the "reasonable officer" standard is used to assess the justifiability of the police use of force (Graham v. Connor, 490 U.S. 386 [1989]; Patrick and Hall 2017). However, reparative justice need not be beholden to traditional legal standards-indeed, it should not be. A norm of reparative justice should apply whenever a police officer kills someone who was not liable to being killed.

Perhaps confusingly, "liability" to being killed is a moral and philosophical notion, not a legal one. With Jeff McMahan's (e.g., 1994, 2005, 2009) work on the ethics of killing, the concept of liability has gained traction as a way of assessing the morality of self-defense. ${ }^{3}$ Selfdefense is not the only reason why police officers use lethal force, but it is the most common reason given, and recent "Blue Lives Matter" activism has moreover focused on the dangerousness of police officers' jobs. Indeed, police officers in the United States do have dangerous jobs. Between 2008 and 2012, an average of 53 officers were killed by civilian attackers annually. ${ }^{4}$ Zimring (2017, 86) computes what this rate means for American police: "In a major city police force of 10,000 officers, a fatal assault risk of 7.1 per 100,000 translates into one killing in an average two-year period." As such, "the threat of lethal attack is a palpable part of being a police officer in the United States."

However, as I argue in the first part of the article, that police officers' jobs are dangerous does not negate the duties that arise in the aftermath of killing a non-liable person. I make this argument by subjecting self-defense in the policing context to philosophical analysis, homing in on the distinction between liability and reasonableness. Liability is typically understood as a "fact-relative" matter. To determine a person's liability to being killed, we can ask, taking an objective standpoint, whether she acted in a way that failed to give the moral rights of others the weight that is due. Reasonableness, by contrast, is an "evidence-relative" matter and has to do with the evidence available to a self-defender that the other person poses a threat. The distinction between liability and reasonableness is important because in the aftermath of a fatal police shooting, officers often refer to the reasonable officer standard, maintaining that any officer at the scene would have been reasonable in using deadly force. But this does not mean that, from a fact-relative standpoint, the shooting was justified. Moral duties arise when a nonliable person is killed regardless of whether it was reasonable to use lethal force. This section also considers the role of implicit racial bias in police killings.
In the second part of the article, I turn to the idea that moral considerations, and not just considerations of legal justifiability, matter to the aftermath of police killings. Reparative justice provides a way for officials to act on those moral considerations. Introducing the notion of "institutional agent-regret," I argue that a reparative justice response is owed even if a police officer acted reasonably in killing a non-liable person. I identify the adversarial structure of traditional civil litigation as an impediment to justice for police killings, one that can moreover perpetuate racial injustice.

In the final section, I address two objections. The first is a worry that reparative justice could be instrumentalized by cities and police departments seeking to enhance their legitimacy in superficial ways. The second concern is that reparative justice unfairly burdens taxpayers.

\section{Self-Defense and Liability in Police- Civilian Interactions}

When police officers use deadly force, they often state that they saw or perceived a gun in the subject's hand ${ }^{5}$ and fired their own weapon in self-defense. ${ }^{6}$ Philosophers generally agree that an agent is permitted to kill someone who, with a gun or by other means, is threatening her life or the life of another. ${ }^{7}$ By threatening someone's life, an agent makes himself liable to defensive harm.

Someone who threatens another person's life intentionally and voluntarily opens himself up to liability on this basis. But McMahan (2005) considers permissible self-defense as extending beyond defensively killing persons culpable in this sense. A person can be liable to defensive harm and be permissibly killed even if she does not "deserve" to die. For example, suppose that someone is driving recklessly, loses control of the vehicle, and is about to kill a pedestrian (Quong 2012, 64). The pedestrian, let us presume, can only save his own life by killing the driver - for example, by throwing a grenade he stumbles on at that moment (Lazar 2009, 720). Though the driver did not threaten the pedestrian's life intentionally or voluntarily, she is liable to defensive harm by virtue of recklessly endangering someone else, and it is permissible for the pedestrian to save himself by killing the driver. ${ }^{8}$

Take another case commonly referred to in the literature (see, e.g., McMahan 2005, 2009; Quong 2012). Suppose that a serial killer is on a rampage in a small town, and all residents are shown his picture and told that he will murder anyone on sight. Implausibly, there exists an unknowingly separated-at-birth identical twin of the killer who happens to have car trouble in this same town. The twin approaches the house of one of the residents, who takes out her gun and is about to pull the trigger. May a superhero observer who grasps the situation - and who is too far away to shout to the resident that she is making a mistake but is within weapon range-kill the resident to save the twin? Most agree that even though the 
resident is no way culpable, she is nevertheless liable to being harmed by the superhero. Acting in self-defense is a risky activity, and if one engages in it, one must know that there is a possibility of making a mistake (Quong 2012). One can acquire liability in the complete absence of culpability.

Since McMahan's initial work on the subject, there is general agreement that liability to defensive harm is a more inclusive and ultimately more important concept in evaluating permissible self-defense than culpability. Disagreement emerges when we ask, "What must a person who does not deserve to die have done to make it the case that he would not be wronged by being killed?" (McMahan 2005, 387).

This question matters deeply for the policing context. US law governing the police use of force is based on the "reasonable officer" standard. This standard gives police officers latitude to make subjective judgments, and even mistakes, about the threat a civilian poses so long as their doing so meets the criteria for "reasonableness." From a moral perspective, depending on the evidence the selfdefender has access to, it is sometimes permissible to use force while making a reasonable mistake that the other person poses a threat. Inflicting defensive harm on the basis of a mistake does not wrong this person if she nevertheless made herself liable. By contrast, it is a serious thing, a moral wrong, to harm a non-liable person. As we see in the case of the serial killer's twin, the reasonableness of a self-defender's action and the other person's liability to defensive harm do not always align. However, in the aftermath of a fatal police shooting, a police department's focus is typically on whether the officer's actions were reasonable, not on whether the civilian was or was not liable. Police departments' failure to make the distinction between reasonableness and liability and to give a civilian's liability independent consideration has important moral consequences.

\section{Reasonableness and Liability}

In the case of an improbably unknowingly separated-atbirth identical twin of a serial killer, the resident believed the twin was about to kill her, but the latter was not a threat and was not liable to defensive harm. But consider the following scenario:

Hostage. A person shows up at a mall with a realistic-looking imitation gun, screams, "I'm going to murder you all!" and pulls a shopper into a supply closet, blindfolding him and barricading the door. The police arrive, and the hostage taker issues threat after threat against the hostage, officers, and shoppers, giving the officers good reason to believe that he is highly dangerous. After several hours of negotiations, the officers break through the door and one kills the hostage taker. As the scene is being cordoned off, the officers see that his only weapon was an imitation gun.?

Despite the obvious difference of the hostage taker seeming to be doing something wrong, Hostage and the twin example—from here on out, "Twin"—-share common features. First, relative to the evidence the resident and the police officers have access to, it is permissible to kill the twin and the hostage taker: inflicting defensive harm is reasonable. ${ }^{10}$ Second, in neither case does the person perceived as a threat actually pose a threat, as the hostage taker cannot kill anyone with an imitation gun. If only these objective facts mattered, then it would be impermissible for the resident to kill the twin and for the police officer to kill the hostage taker. Should a person's liability to defensive harm depend on the evidence or the facts?

In Twin, the twin is non-liable because he did not put anyone at risk; he did not do anything that was potentially hazardous to others. This is a fact-relative matter, but on the evidence, the resident reasonably thinks the twin is a killer about to murder her. Supposing that the resident herself kills the twin (here the superhero has dropped out of the scenario): she has then committed a reasonable act of self-defense against a non-liable person. However, a retrospective evaluation is all we have to assess the twin's nonliability in such a case. An unbiased, hindsight evaluation on the basis of the facts makes it clear that the twin did not do anything to make himself liable. Accordingly, whereas the reasonableness of an act of self-defense should be assessed on the basis of the available evidence, liability should be assessed from a fact-relative standpoint.

However, this does not mean that anyone who, from a fact-relative standpoint, did not put anyone at risk is non-liable. Quong's understanding of liability to defensive harm goes beyond whether a person objectively risks others' lives. On Quong's account, agents may not treat others as if they "lack certain important rights that all persons are generally assumed to possess, or else as if those rights or claims do not have the stringency or moral weight that they do in fact possess" $(2012$, 64). From a factrelative standpoint, the hostage taker treats the shoppers, the hostage, and the police as if their claims do not have the moral weight that is due; he has configured the evidence to make it reasonable for the police to shoot him, endangering the hostage. The hostage taker may not be fully culpable in the way a person with an actual gun would be-he may not, in other words, "deserve" to die—but he is nevertheless liable to being killed.

Let us turn to a case that is quite different from Hostage:

Traffic Stop. A police officer pulls over a motorist at a routine traffic stop, asking for his license and registration. She is trained to be alert to situations in which a civilian is drawing a concealed weapon. As the motorist reaches into his pocket, the officer makes a split-second judgment that this is the gesture of someone about to draw a gun. Thinking she is acting in self-defense, the officer draws her own weapon and fires, killing the motorist. It is soon clear that the motorist had been reaching for his wallet.

Traffic Stop is a case of a non-liable person being killed that is far more extreme than Twin. Twin is set up precisely 
to show that a self-defender can be reasonable in killing a non-liable person. In Traffic Stop, relative to the facts, the driver is clearly non-liable: in reaching for his wallet, he does nothing to violate others' moral rights or to fail to give them the weight that is due. However, it is far from clear that the officer is acting reasonably. Though the officer thought the motorist was reaching for a gun, morally, she is not allowed to defensively kill someone on the basis of this belief in the absence of sufficient evidence. Beliefrelative permissibility does not entail evidence-relative permissibility, in other words (Parfit 2011, 151-52). Assaults on police officers during traffic stops are extremely rare (Lichtenberg and Smith 2001), and in such a context, wallets are a much more common thing for civilians to reach for than weapons. In the absence of exceptional countervailing circumstances - for example, police are on the lookout for a fugitive who has recently shot several officers in the area during traffic stops-the officer's splitsecond decision to shoot was not supported by the evidence she had access to.

But consider a more complicated case:

Imitation Gun. A person is in a public place carrying an imitation gun. The police arrive on the scene, yelling an order for the person to drop his weapon. A split-second later, one officer fires lethal gunshots. The object falls to the ground, and as the officers move in, they see that it is an imitation gun.

Is Imitation Gun closer to Traffic Stop, with an obviously non-liable civilian, or closer to Hostage, where the civilian is liable in spite of lacking the objective means to harm anyone? Context matters in assessing liability. In Japan, a country where gun ownership is rare, a person might be reasonably assumed to pose a threat to others in a scenario like Imitation Gun and be culpable for the decision to display an imitation weapon. However, it is legal to openly carry weapons in most US states. So, even if the officer thinks the imitation gun is real, she is not entitled to assume that the person holding it intends to use it to kill others. As the scenario is written, nothing the person is doing with the imitation gun suggests his harboring homicidal intent, nor does he issue threats as in Hostage. Looking at the scenario from a fact-relative perspective, he is non-liable.

After a police officer kills a civilian, officials often narrowly focus on whether the officer's action was reasonable, ignoring the matter of whether the civilian was liable to being defensively killed. But both unreasonable and reasonable acts of self-defense can involve mistakes about the defended-against person's liability. When an agent makes a mistake, there are distinct moral duties that arise. Say I reasonably interpret an ambiguous set of directions in a way that leads me to the wrong rental property; there I find a key under the mat as expected and enter; or consider a case where everyone's raincoats look alike, and I accidentally take another person's coat (Ripstein 1999, 200). Once my mistake is realized, I am not allowed to stay in the rental property; otherwise this is trespassing. Nor am I allowed to keep someone else's raincoat; otherwise this is stealing. Maintaining that my conduct was reasonable does not mitigate my duties to make things right. I must leave the property and give back the raincoat.

In real-world cases where police officers kill non-liable persons, however, mistakes are rarely admitted. That a police officer's conduct was reasonable is precisely the defense that is given. This defense typically arises in a very specific context, the legal one, but it is not clear why the existence of a legal arena should negate one's moral duties to admit mistakes once they are perceived. A life lost cannot be restored in a way that is analogous to giving back someone's raincoat, but the wrong can be acknowledged and reparations offered. Conversely, a police shooting victim's kin can be wronged not only in a first-order sense, by the loss of their loved one, but also in a second-order sense, by the authorities' failure to admit that their loved one was not liable to being killed and leaving it to the family to bear the entire burden of the loss.

So far it has been argued that reasonableness and liability can come apart. Whereas reasonableness is measured from the standpoint of the evidence to which a would-be self-defender has access, liability depends on the objective facts of the matter: from our hindsight understanding of the situation, did the person who was killed fail to give the moral rights of others the weight that was due? Yet making this judgment is complicated by cases where, objectively speaking, a person imposes a risk of harm on others, but not necessarily lethal harm.

To give an example, police officers sometimes shoot and kill civilians who are threatening them with a knife or a blunt object. It seems that objectively, a knife-wielding civilian does not give sufficient moral weight to the rights of others. However, just because a person is liable to harm of some kind does not mean he is liable to being killed. Necessity is a classic constraint on self-defense. If it is not necessary to kill someone to avoid serious harm to oneself, then it is impermissible to kill in self-defense (Lazar 2012). ${ }^{11}$ Though a person may be fully culpablesuppose a knife-wielding civilian tells an officer, "I'm going to kill you!"- - he is still only liable to the amount of harm necessary to avert the threat. How much harm is this? The civilian's distance from the police officer matters, as well as what he is holding and whether he is stationary, moving closer, or moving away. If an officer aims to stop someone from walking around with a knife because this is a public safety risk, and she can do this by removing a bean-bag gun from her vehicle and firing it, from a moral standpoint, it is impermissible for her to use more harmful tactics.

Of course, when making a split-second decision, it can be difficult to tell whether a person is stationary or moving and how far away he really is. Criminologists Klinger and Brunson (2009) have found that, in lethal-force situations, 
police officers frequently experience stress-related sensory distortions. Because of these distortions, "the decisions that officers make about firing their weapons will frequently be based on perceptions of the situation that do not enjoy a one-to-one correspondence with objective reality" (134). Adrenaline and fear might lead an officer to make a mistake about the nature of the threat a civilian poses and use lethal force when it is unnecessary. As Klinger and Brunson argue, members of the public often misunderstand the experience of police officers who use lethal force, incorrectly using the standard of a calm, composed person who has no perceptual distortions. When "police and public judgments about the appropriateness of specific shooting incidents do not align," write Klinger and Brunson $(2009,136)$, the resulting tensions "are impediments to sound police-community relations." However, what they identify as the public's flawed interpretation of police reasonableness might instead be a tendency to conceptualize a fatal police shooting in terms of the deceased person's liability to this outcome. If the public is being asked to expand its understanding of reasonable lethal force, it seems fair to ask police departments to also give a civilian's liability independent consideration, adopting the standpoint of "objective reality" in doing so.

\section{Liability and Race}

So far, moral liability in the police-civilian context has been examined in the abstract, without considering the role of race. However, I want to claim that there is a distinct racial wrong in killing a non-liable black person.

In the United States, the association of blackness with violence and criminality has a long history (Alexander 2012; Butler 2016, 2017; Davis 2017; Muhammad 2011). It was not uncommon for proponents of slavery to defend the peculiar institution on the basis that black people were prone to crime (Kennedy 1997, 11). American law rendered the power of masters to use force as virtually unlimited, and "slave codes" were used to regulate black behavior and movement, which any white person, not just state officials, could enforce. In the postbellum era, the victims of lynching were disproportionately black males, with an alleged crime-murder, theft, or raping or sleeping with a white woman-spurring the mob into action (Wells 1996). When millions of African Americans left the Jim Crow South for northern urban areas in the Great Migration, the newcomers faced racism, poverty, and segregation. The presence in black areas of a white police force willing to use physical violence was pervasive. "The Negro's most important public contact is with the policemen. He is the personification of white authority in the Negro community," as Gunnar Myrdal $(2017,535)$ wrote. By the 1960s, the practice of lynching had all but ceased, but racialized excessive force by the police did not. The Watts Uprising of 1965 in Los Angeles was prompted by police brutality; echoes of Watts thundered loudly in 1992 when the Los Angeles police officers who beat Rodney King were acquitted, prompting large-scale civil unrest (Saul 2010).

"Innocent until proven guilty" is a hallmark of the American justice system. From Watts to Los Angeles to Ferguson, throughout the twentieth century, African Americans have protested the presupposition of black criminality. Implicit bias research over the last decade has shown just how embedded this presupposition is. If shown a picture of a masked robber, individuals in a simulated juror scenario are more likely to construe ambiguous evidence as suggesting a guilty verdict if the robber is black and a not guilty verdict if the robber is white (Levinson and Young 2009). In a computer simulation directing research subjects to shoot "criminals" brandishing guns and not to shoot "civilians" holding non-weapon objects, both ordinary participants and trained police officers were quicker to shoot black people holding guns and took longer to decide not to shoot those holding non-weapon objects than when the people in the photos were white (Correll et al. 2007). ${ }^{12}$ How does this laboratory finding play out in the real world? For individuals killed by police in a sample studied by Zimring $(2017,59)$, black people were more than twice as likely to be mistakenly perceived as carrying a weapon as white people (see also Lee 2004; Richardson and Goff 2012). ${ }^{13}$

In light of the foregoing, my claim is the following. When a non-liable black person is killed by the police, recognition of this act as having a distinctive racial dimension is owed to the victim's family and community because of (1) the historical meaning embedded in any instance of harming or killing a black person based on a misperception that he or she is a threat, and (2) the racial biases that present-day individuals are shown to have, which make it more likely that a black person will be misperceived as a threat. ${ }^{14}$ The argument for reparations that I make in the next section applies to all cases where non-liable persons are killed by the police, not just nonliable black persons. However, as I later claim, reparative justice measures specifically tied to race are a fitting way of recognizing distinct racial wrongs.

\section{Toward Reparative Justice}

Thus far self-defense scenarios from the policing context have been evaluated solely with reference to moral considerations. In the context of academic articles, the difference between moral standards and legal standards is fairly clear-cut. There may be overlap between the two, but one only needs to specify that one is making a moral but not a legal argument, or vice versa, to avoid confusion between the legal and moral realms. Real-world practice is more indeterminate. In the United States, police officers who use lethal force rarely face criminal repercussions (Butler 2016, esp. 1446-56). According to the standards 
of the law, officers may judge themselves to have been legally permitted, and therefore not wrong, in having used lethal force. Not only might they insist on their permission to have used lethal force under the law but also their lawyers, whose professional duty is to act in their clients' interest, might warn them against saying anything to the contrary. To state that their actions were (morally) wrong is to unnecessarily open themselves up to civil, and possibly criminal, liability-interpreted as within their right to try to avoid. To shield themselves from liability, officers must instead maintain that their actions are ones that any reasonable officer at the scene would have taken.

Reparative justice, as I argue, involves a self-conscious move by government officials to employ moral standards rather than legal standards in the aftermath of a police killing. Legal standards are the default in such cases, and their usage incentivizes actions that can generate fresh moral wrongs on top of the moral wrong of a non-liable person being killed. When a person not liable to being killed is fatally shot by a police officer, the clock cannot be turned back; the victim's life cannot be restored. But the government can do the best thing under the circumstances. It can facilitate full moral accountability to the family when legal standards are at odds with this.

\section{Graham v. Connor and the Reasonable Officer Standard}

When a police officer uses excessive or lethal force, it is typical for administrative, criminal, and civil means of accountability to be seen as the only available options. Administrative responses tend to take place within police departments internally and include verbal reprimands, desk duty, administrative leave, and dismissal. In most US states, a criminal procedure begins with a prosecutor presenting the facts of the case before a grand jury, which then makes a determination whether the officer should face criminal charges. Civil litigation involves the family of the victim suing the officer, police department, and/or city. Like civil litigation, reparative justice is compatible with both an administrative response and charging the officer with a crime.

In civil litigation, there are two outcomes that can lead to the defendant paying compensation: either the defendant is ordered to do so by the court, or compensation is agreed on in a settlement. Civil litigation would seem to be an attractive venue through which justice can be provided. The facts of a given lethal force case are often in dispute, and courts can serve as impartial bodies where a fact-finding inquiry can take place. Civil procedures are moreover designed to be fair to both parties.

However, in US civil law, a great deal of latitude is given to officers in their use of force. Let us consider two examples. First, recall the idea that, for self-defense to be morally permissible, it must be a necessary means of averting a lethal threat. However, as a widely read police manual on self-defense emphasizes, the courts have determined that police officers are not required "to consider alternative levels of force once the "imminent danger' element is satisfied" (Patrick and Hall 2017, 100). What does "imminent danger" mean? According to the manual, it means "simply that the danger could happen at any moment-it does not have to have happened, or be happening yet." Officers are trained to identify "danger signals that are indicative of an imminent attack, such as non-compliance with orders, presence of a weapon or unseen hands, to name a few" (100-1). But defensively killing a person based on signals such as these means that a police officer is almost certainly acting before lethal force has become necessary.

Second, as per the 1989 Supreme Court case Graham v. Connor (490 U.S. 386, 396-97), a "reasonable officer" standard governs the police use of deadly force: "The 'reasonableness' of a particular use of force must be judged from the perspective of a reasonable officer on the scene, rather than with the 20/20 vision of hindsight." This standard, as the majority justices wrote, "must embody allowance for the fact that police officers are often forced to make split-second judgments-in circumstances that are tense, uncertain, and rapidly evolving-about the amount of force that is necessary in a particular situation." ${ }^{15}$ The allowance given to the judgment of the officer on the scene was a crucial aspect of the ruling. As the Sixth Circuit opined in Smith v. Freland (954 F.2d 343, 347 [1992]) three years later,

Thus, under Graham, we must avoid substituting our personal notions of proper police procedures for the instantaneous decision of the officer on the scene. We must never allow the theoretical, sanitized world of our imagination to replace the dangerous and complex world that policemen face every day. What constitutes "reasonable" action may seem quite different to someone facing a possible assailant than to someone analyzing the question at leisure.

Hindsight is unequivocally rejected as the standpoint from which to apply the court's reasonable officer standard. And yet, as I have argued, it is precisely the hindsight point of view from which it is possible to determine that a police officer has killed a non-liable person. Moreover, retrospective reflection on the use of force and an admission that the person killed was not liable to this fate are owed to the victim's family. American law pushes precisely in the opposite direction from moral claims such as these. But reparative justice provides a way for government officials to deal with the aftermath of fatal force in moral, rather than legal, terms.

\section{The Concept of Reparative Justice}

When a police officer kills someone who was not liable to being killed, my argument is that city and police officials owe the family a reparative justice response, offering the family the option of obtaining monetary reparations 
(commensurate with amounts awarded in wrongful death lawsuits), an official apology, and other redress measures that both sides agree to as fair, without having to file a civil lawsuit. ${ }^{16}$ A reparative justice response is owed regardless of whether the police officer acted reasonably or not: it is a way of recognizing the wrong of killing a nonliable person. Here there are important differences between wrongdoing, or "unjustifiable or impermissible harming," and wronging, or "action contrary to rights" (Coleman 2002, 332). Wronging may or may not be accompanied by wrongdoing. But even if no wrongdoing was present, killing a non-liable person is nevertheless contrary to his or her rights. Reparative justice is an attractive way of acknowledging this. ${ }^{17}$

Let us delve into the argument for this claim. In Anglo-American law and beyond, it is a standard idea that compensation is owed for injuries contrary to rights, that it is appropriate as a "secondary response to some previous damage" (O’Neill 1987, 74) ${ }^{18}$ Welfarist accounts stylize compensation as literally correcting an injury: no further claim on the part of the injured party can be made, because a compensated person should be indifferent between her current circumstances and the status quo ex ante. In Nozick's $(1974,57)$ formulation, “it compensates person $X$ for person $Y$ s action $A$ if $X$ is no worse off receiving it, $Y$ having done $A$, than $X$ would have been without receiving it if $Y$ had not done $A$."

Reparative justice builds on the fundamental compensatory idea that something of value is owed for a serious injury, but is concerned precisely with injuries where compensation cannot make a person no worse off than she previously was (Vermeule 2012). Further, reparative justice is relevant in situations where the injurer and injured parties have a past and a future that go beyond the wrong. The relationship, and not only the injury, is in need of repair (Brooks 2004; Walker 2006a, 2006b). In such situations, it is a problem that compensation "by itself need not signal responsibility for injury, much less regret or atonement by those responsible" (Walker 2006b, 385). By contrast, reparative justice can signal responsibility and regret. In a reparative justice framework, monetary redress plays a symbolic rather than compensatory role. It is a way of publicly recognizing that the life lost was valuable.

If one accepts the general idea of reparative justice, it easily follows that a reparative justice response is owed when police kill a non-liable person and the officer acted unreasonably. ${ }^{19}$ It is a serious moral matter for a state to kill one of its political subjects. A reparative justice response shows the family that the city and police department recognize the gravity of the irreparable injury, value the life lost, are willing to do what is in their power to mend a fraught relationship, and acknowledge wrongdoing.

But why should a police department take responsibility, apologize, and pay reparations if a police officer made a reasonable, evidence-based decision that the non-liable individual killed posed a lethal threat-a tragic mistake? To reiterate a previous claim, even if an officer acted reasonably, the non-liability of the person killed itself has moral significance. By definition, a non-liable person does not "deserve" to be killed. Reparative justice carves out space for cities and police departments to recognize the moral significance of what has happened in an area where the law is unresponsive.

However, this response does not go deep enough in explaining the rationale for reparative justice under such circumstances. Let us turn to the notion of what I call institutional agent-regret. In the interpersonal context, agent-regret is distinct from moral responsibility and from regret concerning "states of affairs... [which] can be regretted, in principle, by anyone who knows of them" (Williams 1981, 27). Someone who feels agent-regret laments that the regretful state of affairs was brought about, in whole or in part, by actions stemming from her agency, even if the injury was nonvoluntary. Williams's (1981) famous illustration is the lorry driver who, though driving cautiously, hits a child who runs into the street. Agent-regret explains the qualitatively different reaction of the lorry driver and of someone who reads about the incident in the newspaper. Moreover, we might say that a lorry driver who did not feel agent-regret, who tells the child's parent, "Say what you will, but I'm no more morally responsible for what happened than someone reading about this in tomorrow's paper," exhibits a moral failing. The lorry driver owes it to the parents to acknowledge that it was his vehicle that hit the child and to show he regrets the loss.

Assuming that institutions can be reasonably understood as agents (see, for example, Pettit 2007), the concept of institutional agent-regret seems highly plausible. In the case of police killings, the city and police department owe the family members of the person killed a straightforward admission that their loved one was not liable to this fate and that he died at the hands of a police officer in a tragic accident. And, just as Williams's lorry driver "may act in some way which he hopes will constitute or at least symbolise some kind of recompense or restitution, and this will be an expression of his agentregret" (1981, 28), the city and police department act appropriately in offering reparations. Reparative justice is an appropriate expression of institutional agent-regretand the opposite of doggedly maintaining that, as a matter of law, the officer acted reasonably.

All this being said, however, it is probably rare for a city and police department to bear no responsibility for the evidence-permissible death of a non-liable person. Often in such cases, though a tragic mistake was indeed made, larger structural factors within the police department contributed to the likelihood that a non-liable person would be killed at some point. ${ }^{20}$ When 
institutional structures and practices play a contributory role, the city and police department would be wrong to insist that the death was only an accident and nothing more. In such a case, the death was at the very least foreseeable. The city and police department bear moral responsibility and owe it to the family to admit this. ${ }^{21}$

Before moving on, a final point is worth making. Liability to being killed is a moral notion. It is only as good as the moral reasoning ability of the officials who make use of it. Some might be tempted to apply it as rigidly as they would if it were a legal standard. Again consider the example of a civilian threatening a police officer with a knife or blunt object. Such a person may be liable to being defensively harmed, but is only liable to being defensively killed if lethal force is necessary to avert the threat. It is possible to envision officials splitting hairs over this distinction as a way to delay or avoid paying redress while pressuring the family not to undertake a lawsuit. Officials who do this go against the spirit of reparative justice, which is designed not to be beholden to rigid legal standards. ${ }^{22}$

\section{Adversarial Procedure in Civil Litigation and Settlements}

In the previous section, I referred to the shortcomings of the welfarist model of compensation in explaining the turn to reparative justice: when a life is lost, money cannot make a family no worse off than it previously was. But the civil justice system assigns compensatory damages for wrongful deaths all the time. Why should police killings warrant different standards? My response has to do with the special nature of the relationship between the government and its political subjects and how the process of civil litigation can impair this relationship. In the United States, civil litigation is characterized by adversarial procedure, which can generate new wrongs in the aftermath of a fatal police shooting. This can take place even if a litigated case is eventually settled.

What is adversarial procedure? Returning to the case of Tamir Rice, attorneys for the city of Cleveland answered the Rice family's initial complaint with a brief stating that the 12-year-old boy's death was caused "by the failure... to exercise due care to avoid injury" (Heisig 2016; see also Hooker 2016). This phrase offended Rice's family and sparked widespread public outrage. Yet, it probably would not have been used in any other context but an adversarial civil lawsuit, in which the defendant strategizes to avoid liability. A hallmark feature of Anglo-American legal systems, the adversary method is characterized by the "respective efforts of the opposing attorneys to maximize the interests of their side" (Goodpaster 1987, 124). In the criminal law context, the adversary method is sometimes lauded for being protective of individual rights. Given the high stakes of criminal punishment and the loss of liberty typically entailed by it, a person accused of a crime is provided the most vigorous defense possible. However, as David Luban cautions, the individual rights defense of the adversary method does not apply in the civil context as it does in the criminal one. Yet the same duty falls on the lawyer in both contexts: representing the client "zealously within the bounds of the law" (Luban 2009, 26; here quoting the American Bar Association Code of Professional Responsibility).

Civil litigation often features two private parties opposing each other to determine who should bear the burden of a harm that occurred. But importantly, the government and government representatives are not private parties. Apart from its political subjects' interests, a government is not supposed to have interests of its own. Salus populi suprema lex, as the slogan goes. In cases where a serious wrong is at stake, it is inappropriate for a government to proceed strategically against its own political subjects in the manner of a private party. As a matter of principle, the government should be willing to take on the burden of the harm if a non-liable person was killed by a law enforcement official. In offering reparations, government officials honor this idea.

But, one might argue, when a government settles with the family of a lethal-force victim, it adopts a reparative justice rather than an adversarial paradigm. Moreover, perhaps surprisingly, the high-profile deaths at the center of Black Lives Matter activism have resulted in settlements more often than not. ${ }^{23}$ The lawsuit filed by Tamir Rice's family was eventually settled, and so were lawsuits concerning the deaths of Michael Brown, Freddie Gray, Eric Garner, Ramarley Graham, Rekia Boyd, Walter Scott, Sandra Bland, and Laquan McDonald. It is likely that the settlements in these cases are not representative: in a sample studied by Zimring $(2017,132)$, less than $9 \%$ of police killings resulted in a settlement. However, even in cases where there is a settlement, a monetary payment is not sufficient for justice or moral accountability. The process of civil litigation can undercut the latter, even if a settlement is the eventual outcome.

Consider Laquan McDonald's case, which is unique because Chicago police officers were caught covering up key video evidence of the shooting (Schuppe 2017). Nevertheless, when the teen's family settled, the settlement agreement contained the following phrase: "The City of Chicago denies allegations of wrongdoing and further denies any liability" (Marin and Moseley 2015). Clauses such as this one are ubiquitous in settlement agreements. Though there are legal reasons for their presence, they often speak to municipal officials' selfunderstanding that they are not taking responsibility for the death. This is evident when authorities tell reporters, "The settlement was not a reflection of the Police Department's view of whether the officers did right or wrong but a business decision by insurers" (Kim 2015). Moral accountability requires the opposite of a no-liability 
disclaimer: directly admitting the wrong and the police department's responsibility, and sincerely apologizing. From a reparative justice perspective, legal principles do not provide refuge from one's moral duties. No-liability clauses should be replaced with apologies.

Moreover, before getting to a settlement, cities typically spend hundreds of thousands of dollars in legal fees. The prospect of additional fees in defending against an appeal is often what pushes a city to settle. Then, in determining a settlement, lawyers on both sides strategize to minimize or maximize the payment, going "back and forth like a poker game," as one attorney put it (Kim 2015). ${ }^{24}$ One advantage of reparative justice is that the money that would be spent on legal fees defending the city against the victim's family goes directly to the latter.

A final issue with settlement agreements is that they often contain a provision that forbids the plaintiff from disclosing the contents of the settlement. In some cities, it is standard for settlement agreements to prevent plaintiffs from speaking publicly about the events prompting the lawsuit. ${ }^{25}$ For the family of the victim, a settlement can feel like hush money, a monetary payment in exchange for their silence about wrongdoing. For members of the public, this can also be frustrating, especially when civil lawsuits are settled with taxpayer dollars. Foreclosing information about how much money excessive force is costing taxpayers, and what one's fellow citizen experienced that would prompt a five- or six-figure payment, also goes against basic democratic notions about transparency. Reparative justice rejects secrecy, however. The victim's family may choose a private or a public apology based on their own preferences, but a city may not impose a requirement of confidentiality.

\section{Distinct Racial Wrongs in Adversarial Interaction}

In making the case for reparative justice over civil justice when a non-liable person is killed by a police officer, I have argued that adversarial procedure on the part of the government can lead to its abnegating responsibility for a wrongful death, which itself wrongs victims' families, and that the practice of settling civil lawsuits falls short of demonstrating the kind of moral accountability that reparative justice aims at. Another argument can be added. Earlier it was claimed that when police kill a non-liable person, this is a wrong in itself; when police kill a nonliable black person, there coexists a distinct racial wrong. Similar claims can be made with respect to the treatment of victims' families. In addition to engaging in adversarial procedure, sometimes government officials treat family members as adversaries in their interactions with them and, in doing so, can be insensitive or even cruel. Though any victim's family members can be treated in this way, when the victim is black, again there is a distinct racial wrong.
Consider the aftermath of the fatal shooting of Ramarley Graham, a black teenager, by a white New York City police officer, Richard Haste, in 2012. Graham was shot in his own home; he was followed there by officers who mistakenly thought he had a gun and perceived the teen as "walking with a purpose." Graham's grandmother, Patricia Hartley, was present when Haste burst through the locked door, found Graham in the bathroom, and fatally shot him when he made a movement. When Hartley yelled at the officer about why he shot her grandson, Haste yelled back, "Get the fuck away before I have to shoot you too" (Walsh 2017). The hostility of this statement was indicative of the treatment Graham's family had in store. The police would not let Graham's mother, Constance Malcolm, near the house when she arrived home from work. Without informing her what happened, they drove her to the precinct station, where she met her mother and learned from her that her son was dead. ${ }^{26}$ Ramarley's grandmother was then questioned by officers who pressured her to agree with their claim that Graham had a gun that he had thrown out a window. (No gun was ever found within or outside the apartment.) The evening of the day her grandson was killed, the police detained Hartley for seven-and-a-half hours (Walsh 2017). ${ }^{27}$

Haste was subsequently indicted, but a judge threw out the charges, and a second grand jury chose not to reindict the officer. The family then filed a civil suit. After some time, news outlets reported that the Internal Affairs Bureau of the NYPD was refusing to release the files on Graham's death as a delaying tactic. Constance Malcolm vented her frustration to reporters: "The police are playing games. They're stalling, basically that's what they're doing, they're stalling so the case can't go forward" (Hoffer 2014). The teen's father, Franclot Graham, expressed dissatisfaction that, two-and-a-half years after his son's death, the department claimed it was still investigating the shooting. "We just want our day. We want to be heard, we want to know the facts of what happened," he said. He described a recent visit to his son's gravesite: "I tell him that we're fighting, but we just feel like for some reason, it's a losing battle because nobody's listening to us" (Hoffer 2014).

That black people are disproportionately victimized by fatal police shootings is borne out by the empirics. But when black families are poorly treated by the authorities after losing a loved one to a police shooting, it is not clear how to quantify the phenomenon of race-based secondclass citizenship. Nevertheless, when police departments and municipalities engage in adversarial tactics and refuse to hold their own officers accountable, this is likely to be experienced by the family and community of a black victim as linked to race. A 2017 New York Times op-ed by Constance Malcolm explicitly juxtaposes racial injustice in policing and in the aftermath of police violence, holding the New York City mayor responsible for both: 
In New York City, crime statistics are lower and the overall number of reported stop-and-frisks is down. But black and Latino New Yorkers are still disproportionately stopped, and multiple Police Department audits show that around 64 percent of stops go unreported. This harassment continues even though more than 80 percent of stops don't result in a summons or arrest.

At the same time, there is no accountability for police abuses, which has allowed injustices like my son's killing to go unpunished. Mr. de Blasio is either willfully ignoring racial disparities and Police Department abuses in our communities or has a shallow understanding of the problem. Either way, the harm continues. ${ }^{28}$ (Malcolm 2017)

In a reparative justice paradigm, a deferential, humble attitude toward the victim's family is vital. The authorities should be willing to acknowledge the racial dimensions of any lethal-force death in which the victim is black; they should also be conscious of racial dynamics - for example, if a disproportionately white police force is working in a predominantly black community - that might contribute to the family's experience of racial injustice. Importantly, officials should be willing to work with the family to come up with accountability measures attentive to these racial dynamics. Examples include racial bias training sessions, the establishment of community oversight boards explicitly focused on race and policing, truth and reconciliation commissions on race and policing in the community's past and present, and initiatives to end practices like stop-and-frisk that disproportionately harm people of color.

However, accountability measures not explicitly linked to race may also be an important part of taking racial wrongs seriously. Constance Malcolm, for instance, took issue with the fact that the white officer who killed her son had not been fired when the city settled. On the contrary, he received a significant pay increase while on desk duty. In her op-ed, she expressed her straightforward demand: "New York City must fire all the officers who engaged in misconduct in my son's killing, and ensure the same for officers guilty of misconduct in all incidents of police abuse. These officers are not safe for our communities and need to be off our streets" (Malcolm 2017). Wanting the officers responsible for the death of one's son fired is not necessarily specific to racial injustice. However, it is possible to understand the NYPD's decision to retain Haste and increase his salary as a strong marker of white privilege. If firing an officer who has unreasonably killed a non-liable person is not already a departmental policy, authorities conducting a reparative justice process should take a demand of this nature seriously and honor it.

\section{Objections}

A normative argument has been laid out for municipalities and police departments to take responsibility, apologize, and pay reparations when officers kill persons not morally liable to this fate. Let us briefly consider two objections to this argument. The first objection is based on a worry that governments would use reparative justice to enhance their reputation and perceptions of their legitimacy, but that the underlying system would not change. The second objection has to do with fairness to taxpayers: Isn't a city's defending itself a way to prevent their being overly burdened?

\section{A Superficial Reputation- and Legitimacy-Enhancing Tool?}

In her op-ed, Malcolm (2017) writes about "training, body cameras, police-community relations and neighborhood policing" as "not much more than catchy sound bites." Do reparations risk being viewed the same way by lethal-force victims' families? Indeed, there is a risk of municipal governments embracing reparations as a means of improving the image of police departments while, at the same time, rejecting more fundamental changes.

Two questions are relevant here which should be disentangled: Would reparations be politically instrumentalized, and would reparations preclude more fundamental changes? Let us look at the second question first. Paul Butler (2016, 1466-67) distinguishes between "liberal reform," which can have a "pacifying" effect without fundamentally changing the American criminal justice system, and "actual transformative work" that would overhaul it. A reparations-based approach to police killings could be seen as fitting in with the latter. It requires a complete turnaround in how most police departments and cities react to the shooting of a non-liable person, taking responsibility rather than sloughing it off in a misguided act of institutional self-defense. However, one could still argue that reparations are not sufficiently transformative. To really stop police officers from killing non-liable persons, they may need to stop routinely carrying guns (see Noack 2016). To really stop racialized police killings, we may need to end white supremacy (see Butler 2016, 1434-35 et passim). Taking this into account, the challenge is that de-weaponizing the police and dismantling white supremacy take time. If we wait until there is a sea change in these areas so as to ensure that reparations are part of a transformative, rather than merely reform, project, this meanwhile leaves victims' families wronged by both unjustified lethal force and unjust civil justice.

Accordingly, I suggest that we think of reparations for police killings as part of a mid-range transformative project. Reparative justice would not be needed if the police never used deadly force, but as long as they do, a reparative justice response is a transformation from the existing modus operandi. Reparations for police killings go hand in hand with what can be thought of as another mid-range transformative project: vastly reducing the kinds of situations where the police intervene and instead 
deploying mental health professionals, suicide prevention specialists, drug counselors, child welfare specialists, social workers, and so on. In a society with a more just basic structure (to use Rawlsian language), the number of 9-1-1 calls where we need to be dispatching social workers instead of police officers would probably be reduced. But the normative shift that such changes would be a marker of would also signal a transformative movement to a society with a more just basic structure.

Of course, there is always the risk that governments embrace the idea of reparative justice for the wrong reasons, instrumentalizing the concept to keep demands for more fundamental changes at bay. This challenge, however, is not unique to reparations and speaks to the need for a vigilant public. It will not be lost on victims' families, their supporters, and the media if the government is merely paying lip service to the concept of reparations while refusing genuine accountability.

\section{Fair to Taxpayers?}

Before addressing the objection about whether the city's paying reparations is fair to taxpayers, let me make a caveat. It may be desirable from the standpoint of accountability for an officer who has used lethal force unreasonably to personally contribute to the reparations payment. When New York City settled with members of Akai Gurley's family, they requested a contribution from the officer responsible for his death. The settlement gave the officer four months to pay his share, $\$ 25,000$, of the $\$ 4$ million amount (Fuchs 2016). It need not only be taxpayers who pay.

This being said, one defense of the existing system of civil litigation might be that taxpayers have the right to the best possible defense to prevent their being overly burdened. ${ }^{29}$ Aren't reparations too costly? One response has already been given. Though we do not have good empirical data on how much cities spend defending themselves against civil lawsuits concerning lethal force, the costs are high enough that this can incentivize five- and six-figure settlements. These are costs that taxpayers often already absorb.

But there is a more principled reason why taxpayers should pay. Though there may indeed be "bad apple" police officers, an understanding of any given lethal-force death that focuses solely on individual characteristics is implausible. Decisions about how officers are trained, what they carry, and so on, evolve over time and involve many different responsible agents. Forms of racial bias, both implicit and explicit, influencing a given officer's decision to shoot are similarly shaped by social and historical circumstances. In short, broader political, institutional, and societal factors are likely to bear on the use of lethal force in any particular case. Over the past decade, political philosophers have worked out compelling accounts of why it is fair to distribute the costs of state- sponsored injustice to citizen-taxpayers (see, e.g., Beerbohm 2015; Pasternak 2011; Stilz 2011; Young 2011, ch. 4). Accounts vary-some emphasize that all are responsible for injustice with a "structural" nature, some emphasize associative obligations, and so on-but the idea of citizens sharing responsibility for the state's actions and decisions is a common theme. It is these kinds of analyses that can ground a duty for taxpayers to subsidize reparations for police killings.

\section{Conclusion}

"The sad part about it all is money can never compensate the loss of a son and the loss of a father of four girls." "This is not about money... . Money doesn't bring their son back." "The settlement will never take away the pain that the city caused me." ${ }^{30}$ When plaintiffs' attorneys and victims' family members talk to reporters after receiving a civil settlement, it is typical for them to express the noncommensurability of the money and the harm. Paying reparations will not change this. However, they are a way for the police department and city to apologize, to say "we can at least do better than we have" (Vermeule 2012, 163).

In our existing system, police departments and city officials interpret whether a police officer was justified in fatally shooting a civilian by turning to legal principles. Legal principles and moral principles do not necessarily align, however. As I have argued, morality requires the admission of an error when a person is wrongly killed. This applies to police officers and the government whom they serve, no less than anyone else. The government ought to serve the governed, and it can wrong its political subjects by engaging in defensive, adversarial maneuvers in the manner of a private party in civil litigation. Though the alternative of reparative justice is not a panacea, by design it is responsive to this issue.

\section{Notes}

1 The successful reparations claim of the torture victims of the Chicago Police Department also involved comprehensive reparative justice measures, not just monetary redress (Taylor 2015).

2 In this article, I do not address questions of punishment. The article's goal is to think through reparations as an alternative to civil— but not necessarily criminaljustice. However, it is important to point out that failures of criminal accountability can undercut the moral meaning of a reparations payment: Ray Tensing was not convicted for the death of Samuel DuBose, and to the chagrin of DuBose's family, he received a generous severance package (see note 28).

3 N.B. "Other-defense" considerations are folded in with self-defense considerations and not given an independent analysis in this article. I believe a focus on self-defense is justified because (1) much of the existing philosophical literature focuses on 
self-defense, and (2) empirically, most lethal force cases involve police officers perceiving threats to themselves (Zimring 2017, 63). However, self- and other-defense considerations do not cover all policing fatalities; for example, Eric Garner died in an illegal chokehold, and Sandra Bland died in a county jail cell. Nonetheless, because these individuals were not liable for their fates, the reparative justice standard that I argue for applies to these cases.

4 By contrast, in Germany, just two officers were killed by civilian attackers in this entire period (Zimring 2017, 79).

5 Zimring $(2017,57)$ finds, in the United States, that "the major reason police shoot so often is that guns appear to be in the hands of civilians. Because firearms are also the cause of death in more than 90 percent of all fatal assaults on police, the dominant role of fear of opponents with guns is easy to comprehend" (cf. Butler 2017, 56).

N.B. An officer's ex post facto claim that he fired his weapon in self-defense is not always plausible. For example, Walter Scott, an unarmed black man, was fatally shot in the back by a white officer, Michael Slager, from 15 feet away. An onlooker's video shows the officer subsequently walking over to Scott, handcuffing him (without administering aid), and dropping his Taser on the ground by Scott's body. In his criminal trial, Slager nevertheless testified, "I saw that Taser coming at me... . I fired until the threat was stopped, like I'm trained to do" (Miller 2016, 130; see Hersher 2016).

6 See Miller 2016, ch. 4, and Fabre 2016 on self-defense by police. For the purposes of this article, I follow Fabre's (2016) argument that police officers do not have special self-defense rights beyond those of civilian self-defenders.

7 "Permissibility" and "justification" are distinct concepts; see Tadros 2011, 217-18. In line with recent contributions to self-defense theory, I use the language of "permissible" self-defense rather than "justified" self-defense.

8 Note that in the most frequently debated version of McMahan's scenario, a conscientious driver loses control of her vehicle through no fault of her own. Whereas McMahan (2005) argues that the driver is liable to being killed, others like Lazar (2009) and Quong (2012) disagree.

9 See Draper's (2009, 74-75) case, Mistake II.

10 I follow Parfit's (2011, 150-64) distinction between fact-relative, evidence-relative, and belief-relative permissions and wrongs.

11 Zimring $(2017,97)$ writes, "Attackers who brandish knives and rush at police or who waive blunt objects as they lurch toward an officer never caused a death of an officer in six years. One wonders whether such weapons should really be considered deadly weapons when police in uniform are the targets. If these are not deadly weapons, then the hundreds of killings each year by officers responding to the brandishing of such weapons might not appear to be necessary to protecting the lives of American police."

12 N.B. Though officers and civilians exhibited similar levels of bias in terms of response time, officers (unlike civilians) did not show racial bias in "accurately" deciding when to shoot and not shoot in the simulation.

13 In her work on self-defense theory, Bolinger (2017) argues that, under ideal conditions, it would be desirable to have regulatory norms allowing wellintentioned self-defenders to make mistakes about a person's liability to harm. However, empirical evidence of pervasive racial bias casts doubt on the justice of such norms. Accountability measures should thus interpret mistaken acts of self-defense strictly, and not make allowances for error.

An implication of the account I present in this article may be the idea that criminal justice should be concerned with whether an officer acts reasonably, whereas civil justice (or reparative justice) should be concerned with a civilian's liability. Although assessing this notion further is beyond the scope of this article, I am open to Bolinger's (2017) claim that pervasive racial bias argues for factoring liability into questions of criminal punishment.

14 Though I focus on the black experience in this article, the idea of a distinct racial wrong also applies to Native people, who are often racialized as violent and are killed at similar rates as black people by the police (Zimring 2017, 45). See Woodard 2016 for the Native Lives Matter movement.

15 See Feldman 2017, 338, who argues that Graham allows "legal indeterminacy to produce legal immunity."

16 The concept of reparative justice is not original to this article. For an overview of reparative justice, books edited by Brooks (1999), Roberts (2002), and Miller and Kumar (2007) are all excellent resources. Though Walker (2006b) puts restorative justice and reparative justice in a shared framework, they are more often kept separate, with restorative justice an alternative to traditional criminal justice procedures and reparative justice an alternative to traditional civil justice procedures. I thank an anonymous reviewer for bringing up restorative justice.

17 The focus of this article is lethal force, not excessive nonlethal force. If police departments routinely turned to reparative justice when excessive force does not result in a person's death, I would gladly accept that this follows from my argument, though I do not pursue this matter further here. For more on excessive force, see Skolnick and Fyfe 1994; Kleinig 1996, ch. 6. 
18 Quong (2012, 46, 66ff) has claimed that there is a prima facie duty of compensation when a non-liable victim is killed.

19 Here I do not argue explicitly that it is the city and police department, rather than the individual police officer, that owe a reparative justice response. This matter is discussed in Page (2019).

20 Balko (2013), for example, discusses the increased militarization of US police departments in recent decades.

21 N.B. Though the present article considers reparations to individual families, it is also possible to think that larger-scale reparations are appropriate in the context of a national effort to address harms at the intersection of race and criminal injustice in the United States; see King and Page 2018; Page and King 2019.

22 Of course, there is still the matter of interpreting whether a person was in fact non-liable. An impartial investigation aimed at determining liability is necessary to determine what happened and moreover can have the benefit of giving family members valuable information about how their loved one died. But conducting the investigation as speedily as possible, being transparent about its progress, giving frequent updates, and treating the victim's family with respect are essential for the reparative justice effort to be successful.

23 This is my own claim based on a data set of $50+$ fatalities that have spurred Black Lives Matter protests.

24 Though the attorney interviewed here is referring to use-of-force cases, this characterization of settlement negotiations goes beyond this context.

25 See the case of Ashley Overbey, a Baltimore police brutality victim (Puente and Donovan 2015).

26 According to Malcolm, never once did the police department directly tell her that her son had been killed (Walsh 2017).

27 This is according to Hartley; the NYPD claimed it only detained Hartley for five hours (Walsh 2017).

28 In the op-ed, Malcolm's (2017) main concern is "the lack of accountability for police officers who kill or for police departments that engage in brutality." Though I do think that reparations provide more accountability than civil settlements, termination and forms of punishment may also be needed for accountability. Indeed, even though the civil settlement with Samuel DuBose's family was reparative in its spirit, it was undercut by insufficient accountability on Officer Tensing's part: he faced murder charges, but two trials resulted in two deadlocked juries, and the University of Cincinnati (UC) paid him $\$ 344,230$ on his resignation. As DuBose's fiancée, DaShonda Reid, told reporters: "UC has now reversed any of the rights they attempted to do by Sam. His blood is not only on Tensing's hands [and] the justice system, it's now on UC's hands" (Murphy and Curnutte 2018).

29 Settlements are paid either from a city's general fund or through insurance. Butler $(2017,55)$ suggests that this depends on the size of the city. (Smaller cities use insurance.)

30 The first quote refers to Rumain Brisbon (Frank 2017). The second quote refers to Ricardo Diaz Zeferino (Kim 2015). The third quote refers to Ramarley Graham (Yuhas 2015).

\section{References}

Alexander, Michelle. 2012. The New Jim Crow: Mass Incarceration in the Age of Colorblindness. New York: New Press.

Balko, Radley. 2013. Rise of the Warrior Cop: The Militarization of America's Police Forces. New York: PublicAffairs.

Beerbohm, Eric. 2015. In Our Name: The Ethics of Democracy. Princeton, NJ: Princeton University Press.

Bolinger, Renée Jorgensen. 2017. "Reasonable Mistakes and Regulative Norms: Racial Bias in Defensive Harm." Journal of Political Philosophy 25(2): 196-217.

Brooks, Roy L. 2004. Atonement and Forgiveness: A New Model for Black Reparations. Berkeley: University of California Press.

-., ed. 1999. When Sorry Isn't Enough: The Controversy over Apologies and Reparations for Human Injustice. New York: New York University Press.

Butler, Paul. 2016. "The System Is Working the Way It Is Supposed To: The Limits of Criminal Justice Reform." Georgetown Law Journal 104: 1419-78.

_ 2017. Chokehold: Policing Black Men. New York: New Press.

Coleman, Jules L. 2002. Risks and Wrongs. Oxford: Oxford University Press.

Correll, Joshua, Bernadette Park, Charles M. Judd, Bernd Wittenbrink, Melody S. Sadler, and Tracie Keesee. 2007. "Across the Thin Blue Line: Police Officers and Racial Bias in the Decision to Shoot." Journal of Personality and Social Psychology 92(6): 1006-23.

Davis, Angela J., ed. 2017. Policing the Black Man. New York: Pantheon Books.

Draper, Kai. 2009. "Defense." Philosophical Studies 145(1): 69-88.

Fabre, Cécile. 2016. "War, Policing, and Killing." In The SAGE Handbook of Global Policing, eds. Ben Bradford, Beatrice Jauregui, Ian Loader, and Jonny Steinberg, 261-78. London: SAGE.

Feldman, Leonard C. 2017. "Police Violence and the Legal Temporalities of Immunity." Theory \& Event 20(2): 329-50.

Frank, BrieAnna J. 2017. "Phoenix City Council Approves \$1.5 Million Settlement with Family of Man Fatally Shot by Police." Azcentral.com. http://www.azcentral. com/story/news/local/phoenix/2017/06/29/phoenixcity-council-approves-1-5-million-settlement-familyman-fatally-shot-police/437659001/. 
Fuchs, Chris. 2016. "New York City, Peter Liang to Pay over \$4 Million Settlement to Family of Akai Gurley." NBC News. http://www.nbcnews.com/news/asianamerica/new-york-city-peter-liang-pay-4-1-millionsettlement-n631736.

Goodpaster, Gary. 1987. "On the Theory of the American Adversary Criminal Trial." Journal of Criminal Law and Criminology 78(1): 118-54.

Graham v. Connor, 490 U.S. 386 (1989).

Heisig, Eric. 2016. "City of Cleveland to Pay \$6 Million to Tamir Rice's Family to Settle Lawsuit." Cleveland.com. http://www.cleveland.com/court-justice/index.ssf/ 2016/04/city_of_cleveland_to_pay_6_mil.html.

Hersher, Rebecca. 2016. "Former S.C. Police Officer Takes the Stand at His Murder Trial." NPR. http:// www.npr.org/sections/thetwo-way/2016/11/29/ 503737818/former-south-carolina-police-officer-takesthe-stand-at-his-murder-trial.

Hoffer, Jim. 2014. "The Case of Ramarley Graham Revisited." ABC 7 New York. http://abc7ny.com/news/ the-case-of-ramarley-graham-revisited/270741/.

Hooker, Juliet. 2016. "Black Lives Matter and the Paradoxes of U.S. Black Politics: From Democratic Sacrifice to Democratic Repair." Political Theory 44(4): 448-69.

Kennedy, Randall. 1997. Race, Crime, and the Law. New York: Random House.

Kim, Victoria. 2015. "How Much Is a Life Worth? Calculations behind Gardena’s \$4.7-Million Police Shooting Settlement." Los Angeles Times. http:// www.latimes.com/local/crime/la-me-settlements20150716-story.html.

King, Desmond S. and Jennifer M. Page. 2018. “Towards Transitional Justice? Black Reparations and the End of Mass Incarceration." Ethnic and Racial Studies 41(4): 739-58.

Kleinig, John. 1996. The Ethics of Policing. Cambridge: Cambridge University Press.

Klinger, David A. and Rod K. Brunson. 2009. "Police Officers' Perceptual Distortions during Lethal Force Situations: Informing the Reasonableness Standard." Criminology \& Public Policy 8(1): 117-40.

Lazar, Seth. 2009. "Responsibility, Risk, and Killing in Self-Defense." Ethics 119(4): 699-728. 2012. "Necessity in Self-Defense and War." Philosophy \& Public Affairs 40(1): 3-44.

Lee, Cynthia. 2004. “'But I Thought He Had a Gun’: Race and Police Use of Deadly Force." Hastings Race and Poverty Law Journal 2: 1-51.

Levinson, Justin D. and Danielle Young. 2009. "Different Shades of Bias: Skin Tone, Implicit Racial Bias, and Judgments of Ambiguous Evidence." West Virginia Law Review 112: 309-50.

Lichtenberg, Illya D. and Alisa Smith. 2001. "How Dangerous Are Routine Police-Citizen Traffic Stops?” Journal of Criminal Justice 29(5): 419-28.
Luban, David. 2009. Legal Ethics and Human Dignity. Cambridge: Cambridge University Press.

Malcolm, Constance. 2017. "The Police Killed My Unarmed Son in 2012. I'm Still Waiting for Justice." New York Times. https://www.nytimes.com/2017/02/02/ opinion/the-police-killed-my-unarmed-son-in-2012im-still-waiting-for-justice.html.

Marin, Carol and Don Moseley. 2015. "Six Chicago Police Officers Named in Settlement Agreement." NBC Chicago. http://www.nbcchicago.com/investigations/ laquan-mcdonald-305931691.html.

McMahan, Jeff. 1994. "Self-Defense and the Problem of the Innocent Attacker." Ethics 104(2): 252-90. 2005. "The Basis of Moral Liability to Defensive Killing." Philosophical Issues 15(1): 386-405.

. 2009. Killing in War. Oxford: Oxford University Press.

Miller, Jon and Rahul Kumar, eds. 2007. Reparations: Interdisciplinary Inquiries. Oxford: Oxford University Press.

Miller, Seumas. 2016. Shooting to Kill: The Ethics of Police and Military Use of Lethal Force. Oxford: Oxford University Press.

Muhammad, Khalil Gibran. 2011. The Condemnation of Blackness. Cambridge, MA: Harvard University Press.

Murphy, Kate and Mark Curnutte. 2018. "University of Cincinnati Pays \$250k to Ex-Cop Who Killed Sam DuBose." Cincinnati Enquirer. https://www.cincinnati. com/story/news/2018/03/22/university-cincinnati-payscop-who-killed-sam-dubose/450587002/.

Myrdal, Gunnar. An American Dilemma, Vol. 2. New York: Routledge, 2017.

Noack, Rick. 2016. "5 Countries Where Most Police Officers Do Not Carry Firearms-and It Works Well." Washington Post. https://www.washingtonpost.com/ news/worldviews/wp/2015/02/18/5-countries-wherepolice-officers-do-not-carry-firearms-and-it-workswell/.

Nozick, Robert. 1974. Anarchy, State, and Utopia. New York: Basic Books.

O’Neill, Onora. 1987. "Rights to Compensation." Social Philosophy and Policy 5(1): 72-87.

Page, Jennifer M. 2019. "State Responsibility for Official Wrongdoing." Manuscript on file with author.

Page, Jennifer M. and Desmond S. King. 2019. "Truth and Reparation for Mass Incarceration in the United States." Manuscript on file with authors.

Parfit, Derek. 2011. On What Matters, Vol. 1. Oxford: Oxford University Press.

Pasternak, Avia. 2011. "Sharing the Costs of Political Injustices.” Politics, Philosophy \& Economics 10(2): 188210.

Patrick, Urey W. and John C. Hall. 2017. In Defense of Self and Others, 3rd edition. Durham, NC: Carolina Academic Press. 
Pettit, Philip. 2007. "Responsibility Incorporated.” Ethics 117(2): 171-201.

Puente, Mark and Doug Donovan. 2015. "Brutality Lawsuits Continue in Baltimore, Site of Freddie Gray Death." Baltimore Sun. http://www.baltimoresun.com/sports/bsmd-gray-police-lawsuits-20150422-story.html.

Quong, Jonathan. 2012. "Liability to Defensive Harm." Philosophy \& Public Affairs 40(1): 45-77.

Richardson, L. Song and Phillip Atiba Goff. 2012. "SelfDefense and the Suspicion Heuristic." Iowa Law Review 98: 293-336.

Ripstein, Arthur. 1999. Equality, Responsibility, and the Law. Cambridge: Cambridge University Press.

Roberts, Rodney C., ed. 2002. Injustice and Rectification. New York: Peter Lang.

Saul, Scott. 2010. "Gridlock of Rage: The Watts and Rodney King Riots." In A Companion to Los Angeles, eds. William Deverell and Greg Hise. 147-67. Malden, MA: Blackwell.

Schuppe, Jon. 2017. "Three Chicago Cops Charged With Conspiracy to Cover up Laquan McDonald Killing." NBC News. http://www.nbcnews.com/news/us-news/ three-chicago-cops-charged-conspiracy-cover-laquanmcdonald-killing-n777306.

Skolnick, Jerome H. and James J. Fyfe. 1994. Above the Law: Police and the Excessive Use of Force. New York: Free Press.

Smith v. Freland, 954 F.2d 343 (1992).

Stilz, Anna. 2011. "Collective Responsibility and the State." Journal of Political Philosophy 19(2): 190-208.

Tadros, Victor. 2011. The Ends of Harm. Oxford: Oxford University Press.

Taylor, G. Flint. 2015. "Reparations Won: An Historic Victory in the Struggle against Chicago Police Torture." Police Misconduct and Civil Rights Law Report 11: 1-10.

"University of Cincinnati Reaches \$5.3 Million Settlement with Family of Driver Killed by Police." 2016.
Cleveland.com. https://www.cleveland.com/metro/ 2016/01/university_of_cincinnati_reaches.html.

Vermeule, Adrian. 2012. "Reparations as Rough Justice." Nomos 51: 151-65.

Walker, Margaret Urban. 2006a. Moral Repair. Cambridge: Cambridge University Press.

. 2006b. "Restorative Justice and Reparations." Journal of Social Philosophy 37(3): 377-95.

Walsh, James. 2017. “Can Ramarley Graham's Family Get Justice for His Death?” New York Magazine. http:// nymag.com/daily/intelligencer/2017/06/ramarleygraham-nypd-shooting.html.

Wells, Ida B. 1996. Southern Horrors and Other Writings, edited by Jacqueline Jones Royster. Boston: Bedford/St. Martin's.

Williams, Bernard. 1981. Moral Luck: Philosophical Papers, 1973-1980. Cambridge: Cambridge University Press.

Williams, Timothy and Mitch Smith. 2015. "Cleveland Officer Will Not Face Charges in Tamir Rice Shooting Death." New York Times. http://www.nytimes.com/ 2015/12/29/us/tamir-rice-police-shootiing-cleveland. html.

Woodard, Stephanie. 2016. "Voices from the Movement for Native Lives." In These Times, http://inthesetimes. com/features/native_lives_matter_interview_roundtable. html.

Young, Iris Marion. 2011. Responsibility for Justice. Oxford: Oxford University Press.

Yuhas, Alan. 2015. "Family of Teen Shot Dead by NYPD Vow to Continue Crusade for Police Reform." The Guardian. https://www.theguardian.com/us-news/ 2015/feb/03/ramarley-graham-family-police-reformnypd.

Zimring, Franklin E. 2017. When Police Kill. Cambridge, MA: Harvard University Press. 